\title{
Should the Death Penalty be Discussed in Chinese Classrooms?
}

\author{
Haoxu Geng ${ }^{1, a}$
}

\author{
${ }^{1}$ Institute of Education, University College London \\ astnvhg5@ucl.ac.uk
}

\begin{abstract}
Over the past 20 years, many scholars have argued that young people's civic consciousness and enthusiasm for political participation are in crisis. The proportion of young people involved in political decision-making and voice is declining in many countries. In China, some scholars have proposed teaching public affairs and political issues in high schools to cultivate contemporary teenagers' enthusiasm and ability to participate in political life before adulthood. Choosing the death penalty as the topic of this article is that the death penalty is still practiced in China, and in recent years there have been endless debates on whether to maintain or abolish the death penalty. This paper raises the question of whether the death penalty should be seen as a controversial issue in the Chinese environment and be brought into classroom discussions.
\end{abstract}

Keywords: Controversial issues; The death penalty; Political criterion; Epistemic criterion; Behavioural criterion.

\section{INTRODUCTION}

The debate on the death penalty in Chinese high school classrooms is the subject of this essay. Many observers have claimed a crisis in young people's public awareness and political activity over the last 20 years, claiming that the proportion of young people involved in political decision-making and sharing views has decreased in many nations [3]. Based on the assumption that citizens' political activity in adulthood is inextricably linked to habit-forming during puberty, this pattern seems to mean that democracy is in jeopardy [3]. In China, public relations and political issues have been proposed at high schools to promote the degree of zeal and skill needed to build political ideas among today's youth before reaching adult years [5]. The death penalty was selected as the topic of this essay because it is still used in China, one of the few countries where it is still used. Furthermore, there have been discussions in China over whether the death penalty should be retained or repealed in recent years. This raises the issue of whether or not schools should address the controversial topic of the death penalty.

To address the aforementioned questions, this analysis determines whether the death penalty is a contentious subject based on three categories of parameters: behavioural, political, and epistemic criteria. This article recommends using epistemic principles as the primary criterion for identifying a contentious topic after a critical examination of the three criteria.

\section{THE CONTEXT}

The death penalty is a prescribed means of execution in China, according to Article 33 of the Criminal Law of the People's Republic of China [8]. After the President of the Supreme People's Court issues an execution warrant, Article 251 of the Criminal Procedure Law of the People's Republic of China [7] specifies that the death penalty shall be carried out in jail or a particular location by injection or shooting in private. Despite China's deliberate attempts to limit the number of offences that can result in the death penalty being imposed, there are currently 46 offences that can be dealt with in this manner, making it the country with the most countries that still use the death penalty [16]. According to a 2015 study by Amnesty International, China continued to execute executions that "have not reached the threshold for the most serious crimes under international law, such as economic crimes such as corruption, extortion, kidnapping, and relatively uncommon arson" [22]. Amnesty International also claimed that China imposed the death penalty on Uighur 
Muslims in Xinjiang in a "severe crackdown" against violent crime and religious extremism [22]. In addition, China is considered to be the country with the most significant number of executions each year [13]. Most of the details about the death penalty are referred to as "state secrets" in China. Due to a lack of clarification, the exact number of executions in China cannot be verified. According to a 2017 survey by Amnesty International, between 2014 and 2016, Chinese media announced 931 executions. However, only 85 were recorded in the report, which means that there were at least a few hundred secret death penalty cases. Despite this, the database is defined as representing "true progress in open policy" and is often used to gauge judicial responsiveness and transparency [20]. The Chinese government's concealment of the death penalty issue has influenced the public's perception of and attitude toward the issue. For several years, China's mainstream public opinion has been opposed to the death penalty's abolition. In 2014, the Chinese Social Science Investigation Centre published a death penalty survey, gathering what is believed to be the most significant sample in Mainland China (the successful sample is 31,665 people from up to 25 provinces) [21]. Only 31.7 per cent of respondents who expressly articulated a personal opinion supported eliminating the death penalty, while 68.3 per cent opposed it [14]. Some scholars, however, argue that those opposed to the death penalty may still have a shallow understanding of the topic. Studying surveys of public opinion conducted in China over the last 20 years on the death penalty, Liang Genlin and Chen Eryan [14] found that public views on the death penalty are unstable and unfair. This instability is a concrete reflection of the confusion and changeability of public opinion on the death penalty. The majority of Chinese people are not adamant about abolishing the death penalty. On the opposite, if those who favour the death penalty are granted effective criminal legislation as a solution that will satisfy their social and psychological needs, their support for the death penalty will wane or even reverse. The previous poll decided on using a 'perpetual execution' or a 'death with reprieve' for an alternative to the death penalty by some 77 per cent of the people who favored the death penalty for violent crimes, corruption crimes and economic crimes [14]. In other words, while this 77 percent overwhelmingly supports the death penalty, they are only conditionally in favour of it not being used. This represents the Chinese public's ambivalent attitude toward the death penalty. When asked about their views and beliefs about the death penalty, Liang and Chen [14] found that a certain percentage of respondents prefer "neither agree nor disagree", "refuse to comment", nor "don't know", and other vague Reply. Obviously, in China, people's understanding of the death penalty is still limited and biased. In the absence of understanding of the death penalty of ordinary people, public opinion should not be regarded as rational or used to manipulate the laws and legislation of the country - the death penalty. According to Qi [18], the death penalty is often described as a controversial subject involving state authority and is therefore prohibited from being discussed in classrooms. However, as the influence of citizen dialogue continues to grow, popular opinion is likely to evolve in such a way that it promotes debate of the death penalty decision-making topic, leading to a more severe and systematic examination of the issue. Schools can play a part in this transition by delivering public education.

\section{SHOULD THE DEATH PENALTY BE DISSCUSSED IN SCHOOLS AS A CONTROVERSIAL ISSUES?}

Educational philosophies have not addressed a challenge; typically, three parameters are worth studying: political criteria, behavioural criteria, and cognitive criteria.

Political standards stress public beliefs or principles to be upheld by the administration [12]. In western society, moral questions that cannot be addressed by considering general normative principles should be taught as contentious topics [19]. The problem of the death penalty may be defined as lawful or unlawful by a government and a region's social system. At the moment, 107 countries and regions, including Malaysia, Switzerland, Mauritius, Canada, and others, have eliminated all aspects of the death penalty, accounting for $70 \%$ of the total number of countries and regions globally. However, the death penalty is still legal in Singapore, Japan, and other countries and territories, including Mainland China [9]. Suppose societal principles and morality require a single stance on such philosophical topics; In that case, the subject should not be deemed contentious, and the position should be specifically taught in public schools according to democratic norms [12]. However, as Hand [12] puts it, the task of the school is not to encourage uncritical regard for "the public theory and morality of a democratic society" but to provide students with the knowledge and the skills to address those issues. Even if a democratic state's existing societal principles and moral ideals take a stance on moral questions, this does not prohibit discussion on the topic [1]. Similarly, just because a sovereign state should not take a firm stance on a subject does not mean a better and more defensible position to take. As a result, political criteria are neither necessary nor appropriate for identifying contentious topics in education [1].

The emphasis of behavioural criteria is on social consensus. If a large number of people does not accept the relevant statements and claims on a given issue, the issue is considered controversial, according to behavioural criteria [2]. According to the Chinese Social Science Polling Centre's 2014 public opinion poll of 
31,665 people in Mainland China, 68.3 per cent favoured the death penalty, while 31.7 per cent opposed it. Because of this lack of national consensus, it seems that the death penalty remains a contentious topic dependent on behavioural criteria. Dearden [10], on the other hand, opposes behavioural criteria, stating that controversies often arise in small numbers of people. Even if these questions have simple responses, children may ask them about nation capitals, word spellings, book writers, and explanations of well-known natural phenomena [10]. This means that a subject can be controversial in some circumstances but not in others. As Dearden [10] points out, defining behavioural criteria is a misuse of relativism; his example is worth considering. Assume that in a school where all students accept the death penalty, the topic of the death penalty is not deemed controversial due to disciplinary requirements. In reality, in China, where the death penalty has a substantial degree of support, the condition described above could very well exist. As a result, behavioural criteria cannot decide if the death penalty can be debated in Chinese schools as a contentious topic.

Epistemic criteria, unlike political and behavioural criteria, are concerned with rationality. "When individuals have different views on a subject, and these views are not contradictory to reason, this issue should be taught as a controversial issue," Hand [12] wrote, calling for the implementation of cognitive standards. The term "rationality" refers to public understanding, factual parameters, critical standards and verification processes, rather than any eternal or non-historical [12]. "The main goal of education," Hand [12] wrote, "is to provide students with the ability to think rationally and make decisions." Teachers should encourage students to "provide facts to justify their arguments and help them evaluate. And allow them to only consider claims when the evidence is sufficient" to build arguments. Cognitive standards are considered superior to political and behavioural standards. Epistemic standards may offer the appropriate conditions for recognizing controversial topics, as one of the roles of educators is to improve critical reasoning [1]. According to epistemic criteria, whether or not a topic is considered contentious is determined by whether or not individuals have multiple objective perspectives. Many people have debated whether or not the death penalty should be repealed.

Xinliang Chen [6] maintains that as a country drafts laws and legislation, the decision to abolish the death penalty can be based solely on the assumption of a high moral standard and the fact that executions are incredibly unusual. The sanctity of life is the most fundamental argument used by those who advocate the abolition of the death penalty; hence, the first moral imperative dependent on the sanctity of life should be against killing, not the death penalty. This means that, at least in murder cases, the death sentence is logically irreversible. Xinliang Chen's [6] viewpoint is a reaction to Western countries' theology, which is inspired by religious authority and supports the death penalty's abolition. Abolitionists' theories usually rest on two major foundations. First of all, human life is the product of God's vision of his image. The picture of God can be seen everywhere. Jesus came to save humanity, and the Holy Spirit moved in the soul of man, showing the value of human life. The right to live is in God's hands; therefore, no one may take it away from others or themselves (the Commandment "Thou shalt not destroy" also forbids suicide) [17]. Second, the New Testament stresses that God loves all, including sinners, and that those who repent entirely will be forgiven [15]. Property crimes have not claimed people's lives, but they may be more harmful than murder in the long run. For example, the theft of relief supplies may cause many people to starve to death. Therefore, it is unethical to abolish the death penalty for illegal land activities [6]. Furthermore, supporters of the death penalty believe that although the suffering caused by the death penalty is temporary, the message it sends to future criminals is huge [11]. Of potential killers, the death penalty is the most effective punishment. The death penalty has the potential to deter prisoners from committing offences in the future. Studies in psychiatry and criminology have noted that the benefits of ideological schooling are negligible when it comes to behavior committed against criminals of previous criminal records [23]. Opponents of the death penalty, including Italian political scientist Beccaria [4], contend that it is a violation of the social contract. The right to national criminal law, according to Beccaria [4], stems from the social contract, in which citizens give up some of their rights in exchange for the right to live. The state does not have the power to take away people's rights. As a result, the death penalty is a violation of the general will and the social contract and a violation of freedom.

Furthermore, the death penalty does not have the most effective deterrence effect. Beccaria [4] argues that life imprisonment, rather than the death penalty, is the most effective way to deter violence. He claims that the continuity of the criminal code, rather than the severity of the criminal law, has a more significant effect on the human psyche [4]. Although the scene of the execution of the prisoner is horrific, it is just temporary. The deprivation of freedom is a lengthy and expensive punishment, and this is the most successful way to discourage violence, if the Law allows inmates to use their labour and compensate the society they have hurt" [4]. From the perspective of cognitive standards, the death penalty has rational views and controversial views. 


\section{CONCLUSION}

In a nutshell, this article starts by examining the historical background of China's death penalty. After passing the analysis based on the criteria that define the controversial issues in the classroom, it argues that the death penalty should be debated as a contentious topic based on epistemic criteria in the Chinese context.

\section{REFERECNCES}

[1] Anders, P. and Shudak, N. J., (2016). 'Criteria for Controversy: A Theoretic Approach'. Vol. 39(1), pp. 20-30.

[2] Bailey, C., (1975). 'Neutrality and rationality in teaching'. In Values and authority in schools, Edited

by: Bridges, D. and Scrimshaw, P. London: Hodder \& Stoughton.

[3] Barrett, M. and Pachi, D., (2017). Young Citizenship and Political Engagement. London Routledge.

[4] Beccaria, C., (2016). 'On Crimes and Punishments'. Transaction Publishers. pp. 1-11.

[5] Chen, T., (2007). 'Reflections on the current situation and countermeasures of college students' political participation'. Central China Normal University. Vol. 13(15).

[6] Chen, X., (2003). "Ideal and reality in retention and abolition of the death penalty". Law Science.

[7] China.gov.cn, (2012). 'The death penalty imposed and approved by the Supreme people's Court shall be executed immediately by an order issued by the President of the Supreme people's Court'. Criminal Procedure Law of the People's Republic of China.

[8] China.gov.cn, (2020). 'Criminal Law of the People's Republic of China'. The Standing Committee of the National People's Congress.

[9] CYD., (2020). Debates are popular again in Shanghai High School: I debate, and I am happy. [online] Available at: <http://edu.people.com.cn/n1/2020/0518/c1053-31 712621.html> [Accessed 15 March 2021].

[10] Dearden, R., (1981). 'Controversial Issues and the Curriculum'. Journal of Curriculum Studies, Vol. 13(1), pp.37-44.

[11] Guo, G., (2003). 'The death penalty: retention or repeal?'. Southern Weekly.
[12] Hand, M., (2008). "What Should We Teach as Controversial? A Defence of The Epistemic Criterion", Education Theory. Vol.58 (2), pp. 213-228.

[13] Jeppesen, H., (2019). 'China's death penalty remains the number one'. DW.COM. [online]. Available at: <https://p.dw.com/p/3GYAZ> [Accessed 6 March 2021].

[14] Liang, G. and Chen, E., (2020). 'Public Opinion on the Death Penalty in China: Measurement, Deconstruction and Communication'. Peking University Law Journal, Vol.32(5), pp.1256-1282.

[15] Lindberg, C., (2006). A Brief History of Christianity. Blackwell Publishing. pp.15

[16] Liu, X, (2011). "Lawyer Liu Xiaoyuan: 'China is the Country with the Most Death Penalty Crimes'. [online] The NL. Online. Available at: $<$ https://helanonline.cn/archive/article/2742> [Accessed 6 March 2021].

[17] Olmstead, F., (2013). "The Savior's Use of the Old Testament". Ensign. The Church of Jesus Christ of Latter-day Saints. pp. 46.

[18] Qi, H., (2013) 'Theory of international Chinese language teaching in the "sensitive" and its coping strategies', Journal of Beijing normal university (social science edition), Vol.2, pp.46-53.

[19] Warnick, B. R. and Spencer Smith, D., (2014) The Controversy Over Controversies: A Plea for Flexibility and for 'Soft-Directive'. Teaching Educational Theory. Vol. 64(3): 227-244.

[20] Weng, W., (2017). News | Amnesty International: China has executed at least nearly 1,000 people in three years. Citizen News. [online]. Available at: <https://www.hkcnews.com> [Accessed 6 March 2021].

[21] Xie, Y., Hu, J. and Zhang, C., (2014). 'China Family Panel Studies: Ideas and Practice'. Society. Vol.2, pp.7-11.

[22] Ye, J. and Xiao, E., (2016). 'Amnesty International: The number of death sentences in the world has soared. China Still No.1'. [online] $B B C$ News Chinese. Available at: <https://www.bbc.com/zhongwen/simp/china/2016 /04/160406_amnesty_deaths_china> [Accessed 6 March 2021].

[23] Yu, J., (2005). 'Empirical research report on a survey of views on the death penalty'. Law Review. 